\title{
Differences in urinary proteins related to surgical margin status after radical prostatectomy
}

\author{
ZBYNEK HEGER $^{1,2}$, PETR MICHALEK ${ }^{1,2}$, ROMAN GURAN $^{1,2}$, NATALIA CERNEI $^{1,2}$, \\ KATERINA DUSKOVA ${ }^{3}$, STEPAN VESELY ${ }^{3}$, JIRI ANYZ ${ }^{4}$, OLGA STEPANKOVA ${ }^{4}$, \\ ONDREJ ZITKA ${ }^{1,2}$, VOJTECH ADAM ${ }^{1,2}$ and RENE KIZEK ${ }^{1,2}$ \\ ${ }^{1}$ Central European Institute of Technology, Brno University of Technology, CZ-616 00 Brno; \\ ${ }^{2}$ Department of Chemistry and Biochemistry, Mendel University in Brno, CZ-613 00 Brno; \\ ${ }^{3}$ Department of Urology, 2nd Faculty of Medicine, Charles University, and University Hospital Motol, \\ CZ-150 06 Prague 5; ${ }^{4}$ Department of Cybernetics, Faculty of Electrical Engineering, \\ Czech Technical University, Prague, CZ 12135 Prague 2, Czech Republic
}

Received May 20, 2015; Accepted July 13, 2015

DOI: 10.3892/or.2015.4322

\begin{abstract}
Presented exploratory pilot study was aimed at evaluation of proteins present in urinary specimens collected from prostate cancer suffering subjects after radical prostatectomy, divided into two experimental cohorts: positive $(n=15)$ and negative $(n=15)$ surgical margins (PSM/NSM). The presence of PSM suggests inadequate cancer clearance and the possible need for additional treatment. Proper identification of these risk-patients is therefore of a paramount importance. Total protein profiles were firstly identified by using SDS-PAGE and compared by using partial least square discrimination analysis (PLS-DA), which revealed differences in molecular weights of 80-99 and 150-235 kDa between the experimental groups. For further identification of proteins, comparative proteomic technologies were employed. Two-dimensional gel electrophoresis with subsequent identification of protein spots by using MALDI-TOF mass fingerprinting revealed differential expression of proteins between NSM/PSM cohorts. Moreover, in PSM group, three uniquely identified proteins (cyclindependent kinase 6, galectin-3-binding protein and L-lactate dehydrogenase $\mathrm{C}$ chain) were found, which show tight connection with prostate cancer and presence of all of them was previously linked to certain aspects of prostate cancer. These proteins may be associated with the molecular mechanisms of prostate cancer development; hence, their identification may be helpful for the assessment of disease progression risk after radical prostatectomy, but also for possible early diagnosis.
\end{abstract}

Correspondence to: Professor Rene Kizek, Department of Chemistry and Biochemistry, Mendel University in Brno, Zemedelska 1, CZ-613 00 Brno, Czech Republic

E-mail: kizek@sci.muni.cz

Key words: gel electrophoresis, mass spectrometry, proteomics, partial least squares discriminant analysis, prostate cancer

\section{Introduction}

Prostate cancer $(\mathrm{PCa})$ is one of the most frequent malignant diseases of older men, whose incidence in Northern and Western Europe exceeds 200 new estimated cases $/ 100,000$ and is still growing, especially in the younger age group (35-64 years) (1). In European and North-American countries due to development of demography this disease becomes not only medical, but also an economical issue (2).

The cause of prostate cancer still remains unsolved and only few risk factors are known that affect development of malignant prostate disease. These include increasing age, the black race and hereditary factors $(3,4)$. Not all forms of prostate cancer cause clinically significant disease. According to autopsy examinations $60-70 \%$ of older men die with prostate cancer, however only $3 \%$ of prostate cancer (5). Malignant disease is suspected on the basis of prostate-specific antigen (PSA) levels and palpation of the gland. Definitive diagnosis needs to be confirmed by transrectal needle biopsy.

Unfortunately, even with the sophisticated pre-operative staging techniques, an average of $28 \%$ of those undergoing radical prostatectomy are found to have positive surgical margins (6). A positive surgical margin (PSM) is defined as the presence of tumor at the inked surface of the resected specimen and as such implies incomplete excision of malignant tissue (7). These patients are at increased risk of biochemical relapse, $50-60 \%$ at 5 years, and subsequent clinical relapse, although by no means every patient will suffer eventual disease recurrence (8). Several explanations are given for why a PSM is not always associated with tumor recurrence. The surgery results in ischaemia and fibrosis, both of which may destroy small areas of residual carcinoma as the malignant tissue is unable to survive in its new environment. Alternatively, it may be a result of the desmoplastic response (6).

Evidence from randomized trials suggests that immediate secondary therapy is beneficial for patients with adverse pathology after surgery rather than watchful waiting (9). Since not all of the patients with PSM develop disease recurrence, 
physicians face the challenge of advising an individual on the necessity of secondary therapy. Potential non-invasive monitoring of presence of PSM can be helpful as an auxiliary tool in this decision making process. Recent advances in 'omics'based technologies have greatly facilitated the possibilities to reliably study various types of molecules, linked to different pathological states (10). Among these, proteomics allows the comprehensive identification of broad spectrum of diseasespecific proteins, which are important for detailed description of certain diseases, such as PCa (11). In particular, urinary proteins can serve as an informative tool, simply obtainable in sufficient amounts in non-invasive way.

Our current objective is therefore dual. First, we want to distinguish patients with confirmed PSM or NSM after radical prostatectomy by using sodium dodecyl sulphate-polyacrylamide gel electrophoresis (SDS-PAGE) and its subsequent statistical processing by partial least squares discriminant analysis (PLS-DA). Secondly, we want to identify the major protein differences between the groups by using 2-D PAGE and matrix-assisted laser desorption/ionization time-of-flight mass spectrometry (MALDI-TOF) a powerful tool for proteomics application. Overall, the disparities in expression of urinary proteins in PSM and NSM groups are highlighted.

\section{Materials and methods}

Chemical compounds. All reagents employed for study, as standards, and others were purchased from Sigma-Aldrich (St. Louis, MO, USA) in ACS purity, unless noted otherwise.

Clinical urinary samples. For purpose of this study, urine samples from patients suffering from prostate cancer $(n=30)$, obtained from University Hospital in Motol, Department of Urology, Prague, Czech Republic, were studied (Table I). All the samples were obtained 3 months after radical prostatectomy. Tested patients were divided into two experimental groups. The first one consisted of patients with negative surgical margins (NSM) $(n=15)$. The second group consisted of patients with PSM $(n=15)$. Enlistment of patients into realized clinical study was approved by the Ethics committee (reference EK-377/13).

Tumors were staged according to the 2002 TNM staging system. Extraprostatic extension (pT3a, pT3b) was defined as the extension of the tumor beyond the confines of the gland into the periprostatic soft tissue. A PSM was defined as the presence of tumor at the inked surface of the resected specimen. Histological Gleason grading was performed by a dedicated genitourinary pathologist. Level of serum PSA was measured 3 months after the surgery and this test was performed in a single hospital laboratory under standardized settings.

Determination of total protein in urinary samples. Total protein was quantified using the Skalab 600 M kit (Skalab, Svitavy, Czech Republic), according to the manufacturer's instructions. Measurements were carried out on automated spectrophotometer BS-400 (Mindray, Shenzhen, China).

Acetone precipitation of urinary proteins. Urinary samples (50 $\mu \mathrm{l}$ ) were added to $200 \mu \mathrm{l}$ of acetone. The mixtures were stored for $3 \mathrm{~h}$ at $-20^{\circ} \mathrm{C}$ and further were centrifuged using
Microcentrifuge 5417R (Eppendorf AG, Hamburg, Germany) under $10,000 \mathrm{~g}$ at $4^{\circ} \mathrm{C}$ for $15 \mathrm{~min}$. The pellets were washed with diethylether and ethanol mixture (6:1) and centrifuged $\left(10,000 \mathrm{~g}\right.$ at $\left.4^{\circ} \mathrm{C}, 5 \mathrm{~min}\right)$, then solvent was removed and the pellet was dried on air.

Sodium dodecyl sulphate-polyacrylamide gel electrophoresis (SDS-PAGE). Pellets were diluted in $5 \mu \mathrm{l}$ of ACS water, mixed with protein loading buffer (PLB) in a ratio of 1:1 and incubated at $95^{\circ} \mathrm{C}$ for $5 \mathrm{~min}$ in Thermomixer ${ }^{\circledR} \mathrm{R}$ (Eppendorf $\mathrm{AG})$. Further, samples were removed into the wells in the $12.5 \%$ polyacrylamide gel. Electrophoresis was performed in $1 \mathrm{X}$ Tris-glycine-SDS running buffer for $60 \mathrm{~min}$ in the electrophoretic bath (Bio-Rad, Berkeley, CA, USA) at $110 \mathrm{~V}$. Gels were visualized following protocol of staining with Coomassie brilliant blue staining (12).

Data collection. The decision was made to describe each individual by series of values as curves extracted from electrphoreograms. This approach was chosen among other alternatives namely description of individuals by pairs of band positions and intensities due to its advantages in application of machine learning algorithms. A set of curves can be easily transformed into data matrix in comparison with other descriptions of individuals. The extraction of curves and estimation of molecular weight was made according to ref. 13 . The data collection was facilitated by the MATLAB programming language.

Exploratory analysis. Exploratory analysis was performed by examining tables and plots of the observed data. The transformation was identified to evaluate the raw data on the basis of plots and knowledge of the expected scale of measured variables. Exploratory analysis was used to: i) identify missing and outlying values, ii), verify the quality of the data and find appropriate corrections, and iii) to determine the intervals of spectra used in the projection to latent structure discriminant analysis model relating outputs of experiments to predictors according to the experimental settings.

Statistical modeling. The standard projection to latent structure discriminant analysis models (PLS-DA) were used to find parts of curves differing in examined groups according to experimental settings. The standard PLS 1 algorithm was used to construct latent variables and ordinary least squares were used to determine the coefficients of classification model relating the latent variables to output of the experiment. The leave-one-out validation was used to assess the quality of different models and to choose the correct number of latent variables with respect to the performance of model on the validation data set. The fraction of explained variation R2 was also computed to provide more detailed evaluation of trained models. The interpretation of PLS-DA models was performed by the examination of loading plots and $S$ plots. The interesting parts of curves in relation to the response were pointed out by introducing limits to denominated values in $\mathrm{S}$ plots.

2-D PAGE analysis. Pellets, collected after acetone precipitation were diluted in $125 \mu \mathrm{l}$ of rehydration buffer $(2 \mathrm{M}$ urea, $7 \mathrm{M}$ thiourea, 4\% 3-[(3-Cholamidopropyl)dimethylammonio]- 
Table I. Stratification of the patients from whom urinary samples were collected.

\begin{tabular}{|c|c|c|c|c|}
\hline Patient & $\begin{array}{l}\text { TNM } \\
\text { stage }\end{array}$ & $\begin{array}{l}\text { Surgical } \\
\text { margin } \\
\text { status }\end{array}$ & $\begin{array}{c}\text { Gleason } \\
\text { score }\end{array}$ & $\begin{array}{l}\text { PSA }(\mathrm{ng} / \mathrm{ml}) \text { in } \\
\text { 3rd month after } \\
\text { the surgery }\end{array}$ \\
\hline 1 & pT2a & Negative & $3+3$ & 0.009 \\
\hline 2 & pT2c & Negative & $3+3$ & $<0.005$ \\
\hline 3 & pT2c & Negative & $3+3$ & 0.020 \\
\hline 4 & pT2c & Negative & $3+4$ & $<0.005$ \\
\hline 5 & pT2c & Negative & $3+3$ & 0.031 \\
\hline 6 & pT3a & Negative & $3+3$ & 0.010 \\
\hline 7 & pT3a & Negative & $3+3$ & 0.011 \\
\hline 8 & pT2c & Negative & $3+3$ & 0.006 \\
\hline 9 & pT2c & Negative & $3+3$ & $<0.005$ \\
\hline 10 & pT2c & Negative & $3+3$ & 0.012 \\
\hline 11 & pT2c & Negative & $3+3$ & $<0.005$ \\
\hline 12 & pT2c & Negative & $3+3$ & 0.006 \\
\hline 13 & pT2c & Negative & $3+3$ & 0.019 \\
\hline 14 & pT2c & Negative & $3+3$ & 0.024 \\
\hline 15 & $\mathrm{pT} 2 \mathrm{a}$ & Negative & $3+3$ & 0.005 \\
\hline 16 & pT2c & Positive & $3+3$ & 0.027 \\
\hline 17 & pT3a & Positive & $3+4$ & 0.032 \\
\hline 18 & pT3a & Positive & $3+3$ & 0.409 \\
\hline 19 & pT3a & Positive & $3+5$ & 0.748 \\
\hline 20 & pT2c & Positive & $3+4$ & 0.266 \\
\hline 21 & pT3a & Positive & $3+2$ & 0.044 \\
\hline 22 & pT3b & Positive & $4+3$ & 0.095 \\
\hline 23 & pT3a & Positive & $3+3$ & 0.009 \\
\hline 24 & pT2c & Positive & $3+4$ & 0.011 \\
\hline 25 & pT3b & Positive & $3+4$ & 0.008 \\
\hline 26 & pT3 & Positive & $4+3$ & 0.008 \\
\hline 27 & pT2c & Positive & $3+3$ & 0.034 \\
\hline 28 & pT3a & Positive & $3+3$ & $<0.005$ \\
\hline 29 & pT3a & Positive & $4+3$ & 0.19 \\
\hline 30 & pT2a & Positive & $3+4$ & 0.007 \\
\hline
\end{tabular}

1-15 indicate the patients belonging to NSM group; 16-30 indicate the patients from PSM, both after radical prostatectomy.

1-propanesulfonate hydrate, $100 \mathrm{mM}$ dithiothreitol, $0.2 \%$ ampholyte with $\mathrm{pH} 3.0-10.0,0.001 \%$ bromophenol blue), and the solution was sonicated $(8 \times 2 \mathrm{sec})$. The resulting solution was employed for 12 -h rehydration on 7-cm IPG strips (Bio-Rad). The IPG strips, after rehydration, were focused on Protean ${ }^{\circledR}$ IEF Cell (Bio-Rad) at $20^{\circ} \mathrm{C}$ in 3 steps. In the first step, electric voltage was increased linearly over $20 \mathrm{~min}$ from 0 to $250 \mathrm{~V}$. Second step comprised the voltage increase to $4,000 \mathrm{~V}$ (maintained for $2 \mathrm{~h}$ ). In the third step the electrical parameters were set so that the total value reached $10 \mathrm{kVh}$. The electric current was limited to the value of $50 \mathrm{~mA} / \mathrm{strip}$. After isoelectric focusing, strips were incubated for $10 \mathrm{~min}$ at $25^{\circ} \mathrm{C}$ on a shaker with the First equilibration buffer [6 $\mathrm{M}$ urea,
$20 \% v / v$ glycerol, $2 \% w / v$ SDS, $0.375 \mathrm{M}$ Tris- $\mathrm{HCl}(\mathrm{pH} 8.8), 2 \%$ $w / v$ dithiothreitol]. Thereafter, the solution was replaced and the strips were incubated with the second equilibration buffer [6 M urea, 20\% v/v glycerol, 2\% w/v SDS, $0.375 \mathrm{M}$ Tris- $\mathrm{HCl}$ (pH 8.8), $2.5 \% w / v$ iodacetamide, $0.001 \%$ bromophenol blue] for $10 \mathrm{~min}$. Strips, prepared in this manner were washed in Tris glycine-SDS running buffer. The strips were then placed on the back of the flatbed electrophoretic glass plate. Subsequently, the agarose was poured between the plates, where the strip was inserted. After solidification of agarose, the plates were inserted in the electrophoretic bath with Trisglycine-SDS running buffer. Electrophoresis was set to $75 \mathrm{~min}$ at a voltage of $180 \mathrm{~V}$. Gels were stained using Coomassie brilliant blue and silver (12).

In-gel tryptic digestion. For excision of the spots from 2D gels of urinary samples EXQuest ${ }^{\mathrm{TM}}$ SpotCutter (Bio-Rad) was utilized. The in-gel digestion with trypsin was performed according to a protocol of Shevchenko et al (14). The digests of proteins were further employed for peptide mass fingerprinting (PMF).

Matrix-assisted laser Desorption/Ionization time-of-flight (MALDI-TOF). The mass spectrometry experiments were performed on a MALDI-TOF mass spectrometer Bruker ultrafleXtreme (Bruker Daltonik GmbH, Bremen, Germany), using 2,5-dihydroxybenzoic acid as matrix. The saturated matrix solution was prepared in $30 \%$ acetonitrile and $0.1 \%$ trifluoroacetic acid. Mixture was thoroughly vortexed and ultrasonicated using Bandelin 152 Sonorex Digital 10P ultrasonic bath (Bandelin Electronic, Berlin, Germany) for 2 min at $50 \%$ of intensity at room temperature. For sample preparation the dried-droplet method was utilized, where solutions of digested proteins were mixed with matrix solution in volume ratio of 1:1. After obtaining a homogeneous solution, $2 \mu \mathrm{l}$ was applied on the MTP 384 polished steel target plate (Bruker Daltonik $\mathrm{GmbH}$ ) and dried under atmospheric pressure at $25^{\circ} \mathrm{C}$. All measurements were performed in the reflector positive mode in the $\mathrm{m} / \mathrm{z}$ range $400-6,000 \mathrm{Da}$. The MS spectra were typically acquired by averaging 500 sub spectra from a total of 500 shots of the laser with laser power set $5 \%$ above the threshold.

Peptide mass fingerprinting. Peptide mass fingerprinting (PMF) was done using MASCOT server (Matrix Science, Boston, MA, USA) for comparing mass spectra with UniProt database. For database search the following parameters were used: trypsin was used as the enzyme, zero or one missed cleavage was allowed, taxonomy was set to Homo sapiens, oxidation of methionine or/and $N$-term acetylation was added as variable modification, peptide tolerance was set to $\pm 0.5 \mathrm{Da}$, mass values were set as $\mathrm{MH}^{+}$and were obtained from monoisotopic peaks.

\section{Results and Discussion}

Urine is a specific filtrate of blood; the protein components of urine are qualitatively similar to those of blood but much more diluted (15). An advantage for urine over blood is that urinary proteins are stable and do not undergo significant proteolysis within several hours of collection. Hence, urinary proteomics 


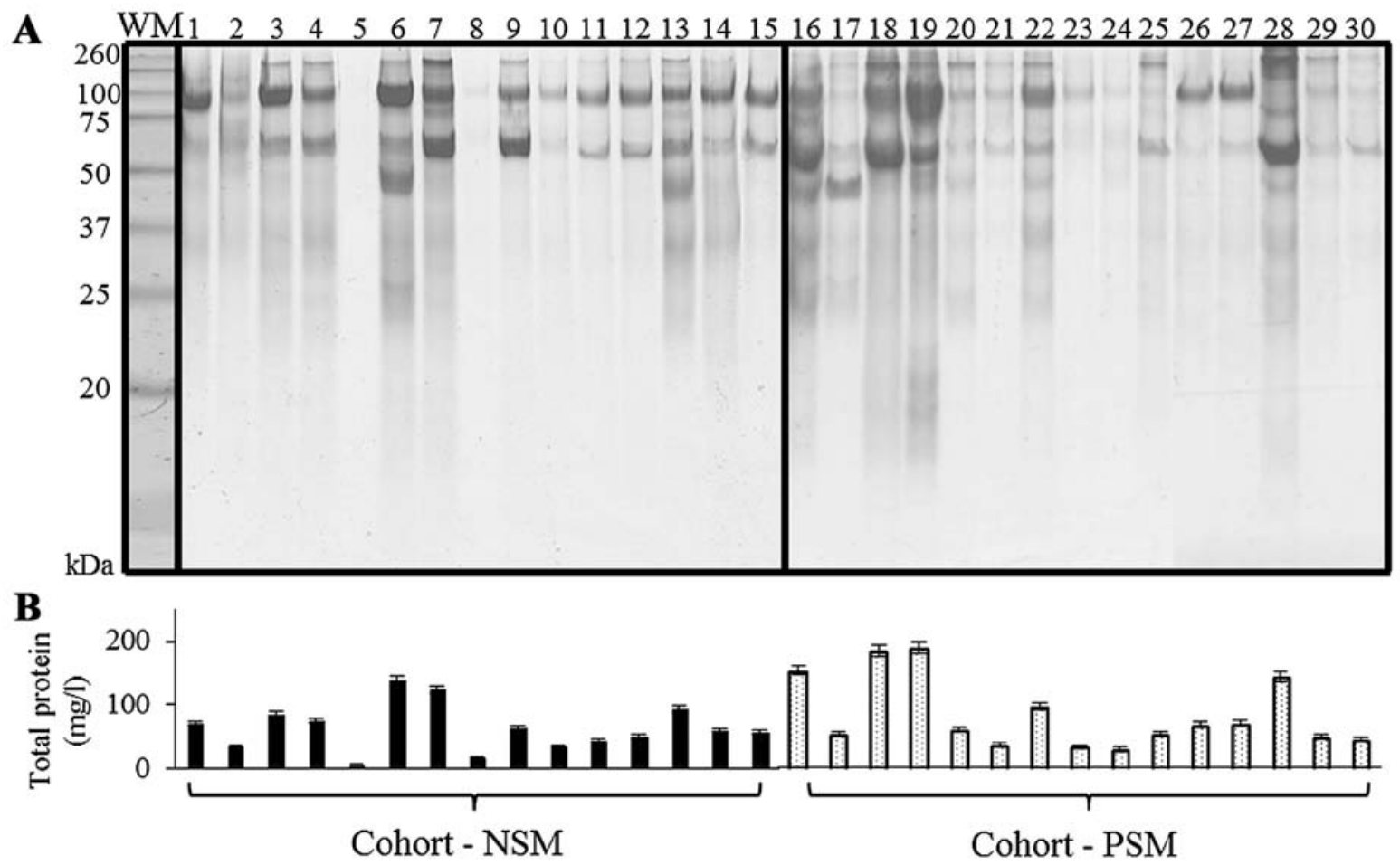

Figure 1. (A) SDS-PAGE of urinary proteins after acetone precipitation of both cohorts of patiens [lanes 1-15, patients with negative surgical margins (NSM); lanes 16-30, patients with positive surgical margins (PSM), both observed after radical prostatectomy]. WM, weight marker (kDa). Specific conditions of preparation of SDS-PAGE are given in 'Acetone precipitation of urinary proteins and SDS-PAGE' in Materials and methods. (B) Summary of total protein in individual samples (1-30), determined spectrophotometrically by using pyrogallol red method.

presents an attractive approach to cancer biomarker discovery, not only for urological malignancies (16), but for other systemic malignancies and evaluation of current health status (17). Many advantages favor the use of urine over blood and tissues samples, including the fact that urine-based tests are non-invasive, and urine is non-infectious for HIV and less infectious for many other pathogens (18).

Evaluation of total protein profiling by SDS-PAGE and its statistical processing. The migration of the molecular weight marker and urinary proteins of NSM, PSM patients on SDS-PAGE is presented in Fig. 1A. SDS-PAGE is a rapid and simple technique for protein pattern elucidation, quantification and determination of groups of proteins with similar molecular weight $\left(M_{\mathrm{r}}\right)(19)$. The visualization of NSM/PSM groups revealed proteins with relatively wide range of $M_{\mathrm{r}}$ that, according to previously published results, correspond to commonly present albumin $\left(M_{\mathrm{r}} 60-70 \mathrm{kDa}\right) ; 80-110 \mathrm{kDa}$ range belongs to transferrin and uromodulin (formerly TammHorsfall protein), together with albumin polymeric complexes can be determined, in $160-200 \mathrm{kDa}$ range the major band is commonly dedicated to $\operatorname{IgG}, \operatorname{Ig} \mathrm{A}$ monomers and $\mathrm{C}_{3}$. Less distinct bands at $M_{\mathrm{r}} 31 \mathrm{kDa}$ were previously linked with carbonic anhydrase (20-22). For confirmation, total proteins in urinary specimens were quantified spectrophotometrically (Fig. 1B). Higher protein levels were determined in PSM cohort $(85.3 \pm 55.9 \mathrm{mg} / \mathrm{l})$ when compared to NSM one (mean $64.1 \pm 36.2 \mathrm{mg} / \mathrm{l})$.

Since our first aim was the determination of NSM/PSM SDS-PAGE protein patterns we employed partial least square
Table II. The evaluation of partial least square discriminant analysis (PLS-DA) model.

\begin{tabular}{lccc}
\hline Model & $\begin{array}{c}\text { Performance } \\
\text { on the } \\
\text { validation set }\end{array}$ & $\begin{array}{c}\text { Fraction of } \\
\text { explained } \\
\text { variation }\end{array}$ & $\begin{array}{c}\text { Estimated no. } \\
\text { of latent } \\
\text { variables }\end{array}$ \\
\hline NSM/PSM & $83.33 \%$ & $50.20 \%$ & 1 \\
\hline
\end{tabular}

discriminant analysis (PLS-DA) model, which utilized curves (band intensities) extracted from SDS-PAGE gels. To facilitate the comparability of curves the linear interpolation of all curves was carried out to identical values of molecular weight. Carrying out the linear interpolation a pair of limits was introduced to exclude marginal parts of curves and the linearization of molecular weight was performed. The leaveone-out validation was carried out to assess the prediction quality of the model and to choose the number of latent variables according to the prediction accuracy criterion. The results of leave-one-out validation of PLS DA model are presented in Table II.

As seen in Fig. 2A, in our NSM/PSM model the proteins in mass ranges of $80-99$ and $150-235 \mathrm{kDa}$ were evaluated as the most significant in discrimination between examined groups. The quadrant expression based on comparison of the curves projection shows separate distribution of both NSM and PSM groups (Fig. 2B).

Obtained results revealed interesting disparities in protein patterns; however co-migration of proteins with similar 
A

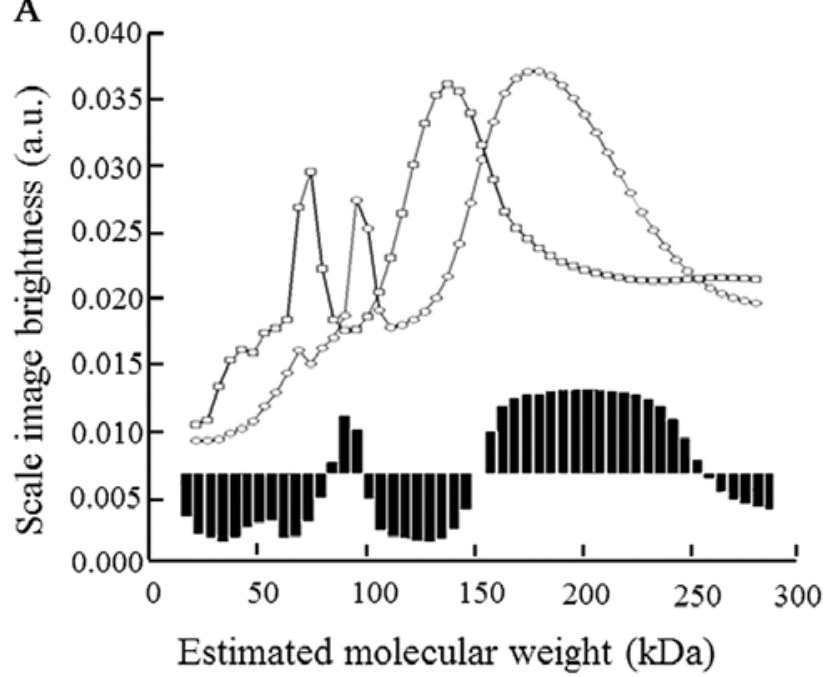

B

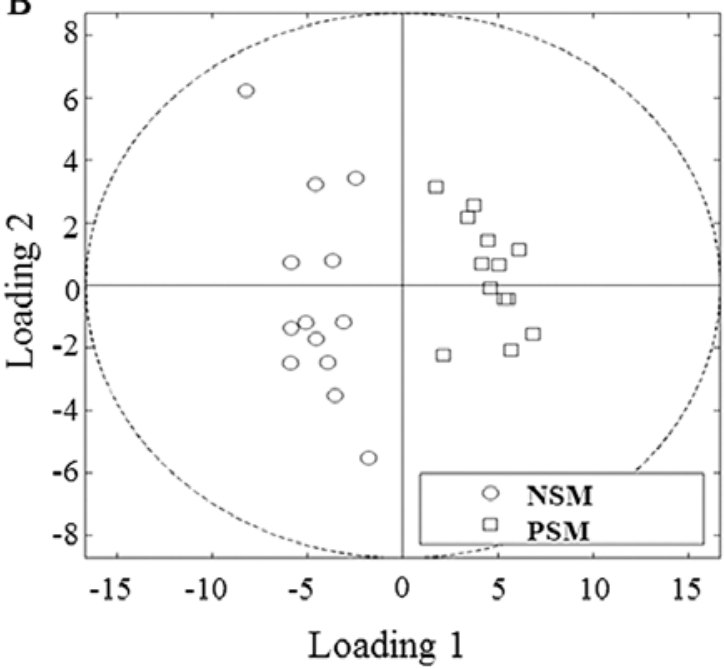

Figure 2. Statistical processing of SDS-PAGE of urinary samples expressed as PLS-DA results, where circle indicates subjects with NSM and square the subjects with PSM. Insert, the loading plot presentation of differences between curves of NSM and PSM patients. The highest bars (80-99 and 155-250 kDa) indicate the most effective parts, reflected in latent variable, showing the most significant differences in protein composition. (B) The quadrant expression of comparison of SDS-PAGE, obtained from NSM subjects (circle) and PSM subjects (square). One point in the graph represents the projection of the whole curve.

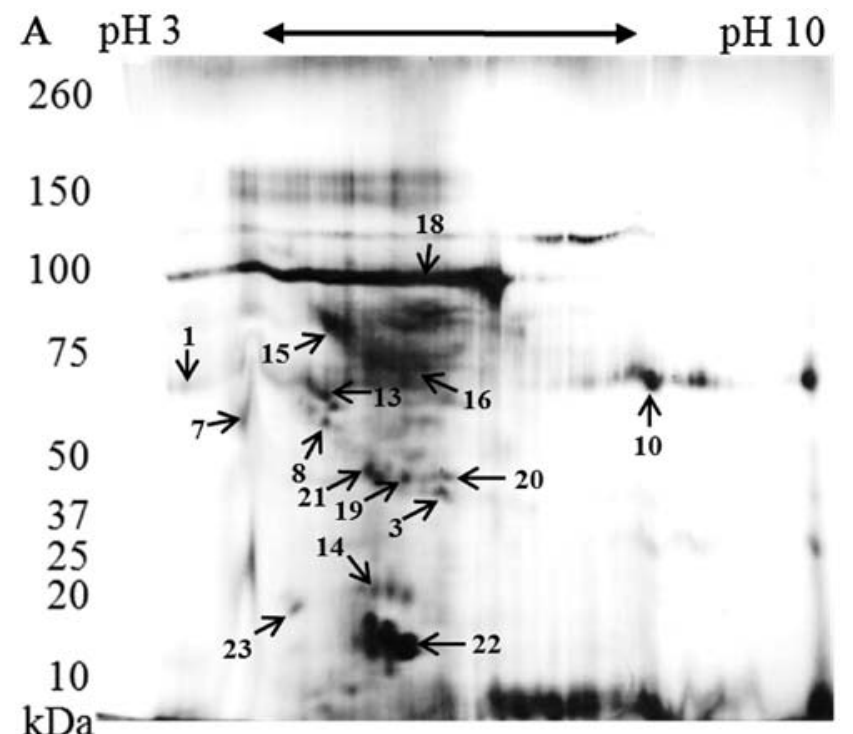

B

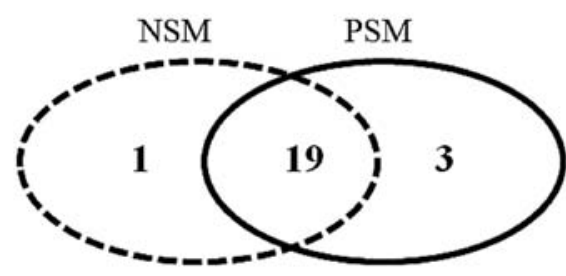

Figure 3. (A) Proteome map (subject 19 from the PSM group), obtained via 2-D electrophoresis. The protein separation was based on their differential $\mathrm{pH}$ value for the isoelectric point ( $\mathrm{pI}$; $\mathrm{x}$-axis) and molecular weights (y-axis). The protein spots were excised and underwent in-gel tryptic digestion followed by MALDI-TOF MS. The number labeling in the figure corresponds to the numbers of proteins listed in Table III. (B) Diagram showing number of overlaping and unique proteins obtained from analyses of urinary samples of PSM and NSM cohorts.

mass decreased the separation yields and thus better separation method was required for further analyses of proteins of interest.
2-D electrophoresis and PMF. Because two-dimensional gel electrophoresis employs both isoelectric focusing of target molecule, its $M_{\mathrm{r}}$ and it is unlikely that two molecules will be similar in two distinct properties, higher separation resolution is provided (23). We analyzed urinary protein profiles of patients with NSM $(n=15)$ and PSM $(n=15)$ by using acetone precipitation for proteins isolation with subsequent 2-D electrophoresis and MALDI-TOF identification.

Following 2D-PAGE and staining, the most prominent spots were picked up for the MS analysis. Their positions in the 2-D map of representative subject belonging to PSM group are shown in Fig. 3A. Some proteins were presented as a horizontal row of multiple spots (with small changes in $\mathrm{pI}$ and molecular weight), likely caused by variable posttranslational modifications (24). The identified proteins and their characteristics are shown in Table III. It was revealed that majority of proteins (19 overlaping proteins) can be identified in both groups. In both, PSM and NSM groups, unique proteins were found ( $n=1$ in NSM; $n=3$ in PSM) as depicted in Fig. 3B.

The identified proteins were further classified using the data from the UniProt Knowledgebase. As shown in Fig. 4A, belonging to PSM group, regarding to molecular functions, most of identified proteins (46\%) have binding function, which was followed by catalytic activity, transport and organization of cellular components. Proteins $(21 \%)$ were involved in response to stimuli, followed by cellular and metabolical processes $(18 \%)$. One third of identified proteins are enzymes $(35 \%)$ and most of proteins had extracellular region location $(41 \%)$. The majority of extracellular proteins is related to close contact of urine with glands in the male urinary tract and fact that significant fraction of urinary proteins is derived from plasma (25). In NSM group (Fig. 4B), lower portion of binding proteins $(37 \%)$ was observed with increase of transport proteins $(21 \%)$ and proteins responsible for organization of cellular components (24\%). Further, in NSM group, decreased number of enzymes was identified and in four 


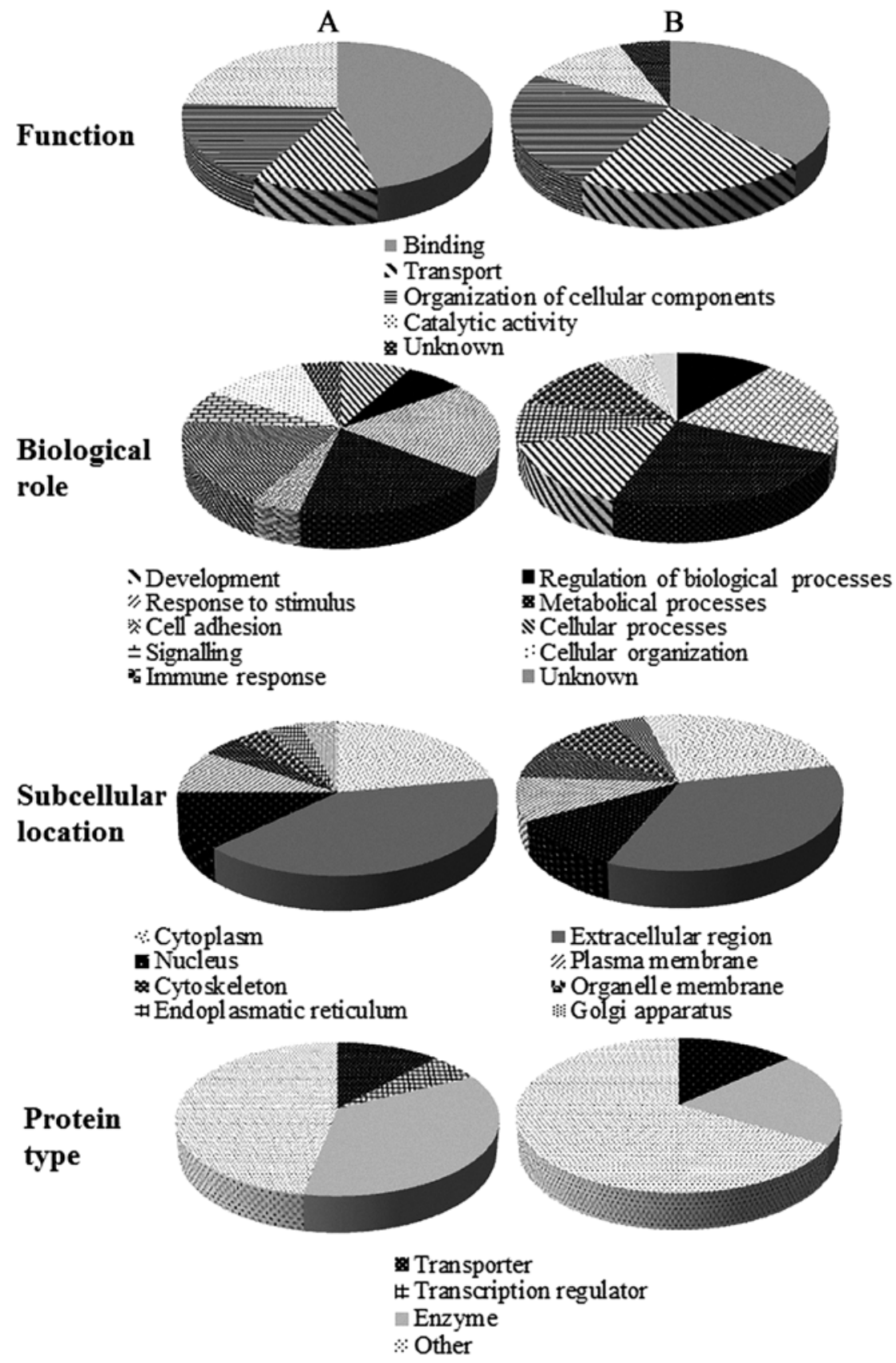

Figure 4. Diagrams showing classification of the identified proteins in urine of (A) PSM and (B) NSM cohorts. The molecular function, biological processes in which they are involved, subcellular location, and type of protein were evaluated by using UniProt database. All the proteins identified in each group were employed in the evaluation.

subjects, elevated expression of testis-expressed sequence 33 protein (TEX33_HUMAN), protein with unknown function and biological role, was determined. In NSM cohort, higher abundance of E-cadherin, calcium $2^{+}$-dependent cell-adhesion protein, maintaining homeostasis (26), was determined. Several reports show that E-cadherin is tumor-invasive suppressor and decreased cadherin expression has been associated with more advanced tumor stage, grade and poor prognosis in PCa (27-29). Shimamura and coworkers demonstrated that patients suffering from pancreatic adenocarcinoma with downregulated E-cadherin had a tendency to have PSM (30). $\alpha$ fetoprotein, potential tumor biomarker (31), was identified $(27 \%)$, in lower abundance in NSM group, which points at possible higher relapse potential of PSM subjects. Another interesting finding was the disparity in urinary prostatic acid phosphatase (Table III). In 1936 Gutman and coworkers observed that serum activity of this enzyme is significantly higher in PCa patients, especially suffering from osteoplastic metastases (32), and it was extensively used for PCa diagnosis prior to introduction of PSA (33). Our results demonstrate that PSM cohort comprises more subjects, whose urinary specimens contain detectable levels (73\%) of prostatic acid phosphatase when compared to NSM group (37\%). In NSM cohort, also higher abundance of plasminogen (angiostatin), potent inhibitor of angiogenesis (34), was determined.

From all identified proteins, 3 unique proteins have been determined in PSM group, whose expression in NSM group is downregulated to undetectable levels. All of them (cyclin- 
Table III. Expression of basic characteristics and abundance of proteins (\%), identified in both groups (NSM, n=15, PSM, n=15) after in-gel tryptic digestion and MALDI-TOF identification.

\begin{tabular}{rllrrrrr}
\hline No. & \multicolumn{1}{c}{ Protein } & $\begin{array}{r}\text { UniProt } \\
\text { accession entry }\end{array}$ & $\begin{array}{c}\text { Predicted } \\
\text { mass }\left(M_{\mathrm{r}}\right)\end{array}$ & pI & $\begin{array}{c}\text { Approx. } \\
\text { MASCOT score }\end{array}$ & $\begin{array}{c}\text { NSM } \\
(\%)\end{array}$ & $\begin{array}{c}\text { PSM } \\
(\%)\end{array}$ \\
\hline 1 & a-fetoprotein & FETA_HUMAN & 70.1 & 4.57 & 402 & 27 & 53 \\
2 & AT-rich interactive domain-containing & ARI1A_HUMAN & 242.0 & 6.08 & 367 & 67 & 27 \\
& protein 1A & & & & & & \\
3 & Cyclin-dependent kinase 6 & CDK6_HUMAN & 36.9 & 6.02 & 358 & - & 40 \\
4 & E-cadherin & CADH1_HUMAN & 99.1 & 4.50 & 211 & 87 & 34 \\
5 & Fascin & FSCN1_HUMAN & 54.5 & 5.50 & 663 & 73 & 53 \\
6 & Fatty acid-binding protein, intestinal & FABPI_HUMAN & 15.2 & 5.30 & 258 & 27 & 40 \\
7 & Galectin-3-binding protein & LG3BP_HUMAN & 65.3 & 4.90 & 559 & - & 53 \\
8 & Keratin,type I cytoskeletal 10 & K1C10_HUMAN & 58.8 & 5.10 & 398 & 67 & 87 \\
9 & Keratin,type I cytoskeletal 9 & K1C9_HUMAN & 62.0 & 4.90 & 157 & 94 & 53 \\
10 & Keratin,type II cytoskeletal 1 & K2C1_HUMAN & 66.0 & 8.10 & 304 & 73 & 67 \\
11 & L-lactate dehydrogenase C chain & LDHC_HUMAN & 36.2 & 7.08 & 456 & - & 27 \\
12 & Plasminogen & PLMN_HUMAN & 93.2 & 6.20 & 198 & 67 & 40 \\
13 & Protein disulfide-isomerase A4 & PDIA4_HUMAN & 72.9 & 5.16 & 264 & 60 & 73 \\
14 & Retinol-binding protein 1 & RET4_HUMAN & 20.5 & 5.76 & 441 & 73 & 67 \\
15 & Transferrin & TRFE_HUMAN & 79.3 & 5.20 & 280 & 87 & 94 \\
16 & Serum albumin & ALBU_HUMAN & 69.3 & 4.70 & 360 & 100 & 100 \\
17 & Testis-expressed sequence 33 protein & TEX33_HUMAN & 30.7 & 5.65 & 256 & 27 & - \\
18 & Uromodulin & UROM_HUMAN & 95.0 & 5.05 & 762 & 100 & 94 \\
19 & Acid phosphatase, prostate & PPAP_HUMAN & 44.5 & 5.89 & 256 & 37 & 73 \\
20 & Guanine nucleotide binding protein & GBLP_HUMAN & 40.4 & 5.69 & 401 & 53 & 67 \\
21 & Serine proteinase inhibitor, clade A & A0A024R6N9_HUMAN & 46.6 & 5.42 & 301 & 34 & 53 \\
22 & CD59 glycoprotein & CD59_HUMAN & 14.2 & 6.02 & 299 & 53 & 87 \\
23 & Lithostathine-1- $\alpha$ & REG1A_HUMAN & 18.7 & 5.00 & 178 & 87 & 73 \\
\hline
\end{tabular}

The identified proteins including the UniProt identification number, predicted $\mathrm{pI}$ and the molecular weight $(\mathrm{kDa})$ are summarized. All of the proteins showed on Fig. 3 are in the expected range of $\mathrm{pI}$ and molecular weight.

Table IV. Characterization of functions of the 3 unique proteins found only in the PSM group.

\begin{tabular}{|c|c|c|c|c|c|}
\hline Protein & Gene & $\begin{array}{l}\text { Subcellular } \\
\text { location }\end{array}$ & Biological function & $\begin{array}{c}\text { Described } \\
\text { linkage to } \mathrm{PCa}\end{array}$ & (Ref.) \\
\hline $\begin{array}{l}\text { Cyclin-dependent } \\
\text { kinase } 6\end{array}$ & CDK6 & $\begin{array}{l}\text { Nucleus, } \\
\text { cytoplasm }\end{array}$ & $\begin{array}{l}\text { Control of cell cycle and differentiation, } \\
\text { promotes } G_{1} / S \text { transition }\end{array}$ & Yes & (36) \\
\hline $\begin{array}{l}\text { Galectin-3-binding } \\
\text { protein }\end{array}$ & $L G A L S 3 B P$ & $\begin{array}{l}\text { Extracellular } \\
\text { region }\end{array}$ & $\begin{array}{l}\text { Promotes integrin-mediated cell } \\
\text { adhesion, stimulate host defense } \\
\text { against tumor cells }\end{array}$ & Yes & (37) \\
\hline $\begin{array}{l}\text { L-lactate dehydrogenase } \\
\text { C chain }\end{array}$ & $L D H C$ & Cytoplasm & $\begin{array}{l}\text { Possible role in sperm motility, conversion of } \\
\text { L-lactate and NAD to pyruvate and NADH } \\
\text { in anaerobic glycolysis }\end{array}$ & Yes & (38) \\
\hline
\end{tabular}

dependent kinase 6, L-lactate dehydrogenase $\mathrm{C}$ chain and retinol-binding protein) were determined in more than one case (27-67\% abundance), which points to their possible connection with presence of residual tumor tissue. The list of these proteins with a description of their biological role is shown in Table IV. 
The identified proteins, unique for PSM cohort were previously described in certain aspects of prostate cancer development. Cyclin-dependent kinase 6 (CDK6) binds to and is activated by cyclin D1 and thereby enhances the transition of cells through the $\mathrm{G}_{1}$ phase (35). The regulation is performed through regulation of the phosphorylation state of retinoblastoma protein $(\mathrm{pRb})$. When hyperphosphorylation of $\mathrm{pRb}$ occurs, it leads to release of transcription factors, which enhance progression of the cell cycle (36). Since the dysregulation of the cell cycle is one of the defined hallmarks of cancer (37), Palbociclib, oral inhibitor of CDK4/6, was developed to manage $\mathrm{ER}^{+}$and HER2 amplified breast tumors (38). In prostate cancer only slight evidence exists pointing to a role of CDK6. Lim et al (35) demonstrated that CDK6 can easily bind to the androgen receptors (AR), which play a pivotal role in prostate cancer (39), and it was revealed that CDK6/AR binding stimulates transcriptional activity in presence of dihydrotestosterone (35). Moreover, they have shown that androgen-sensitive LNCaP PCa cells, engineered to stably overexpress CDK6 display increased elevated PSA expression and enhanced growth attributes. The same group indicates that CDK6 is overexpressed in $44 \%$ of PCa; hence presence of this protein in urine could be clinically interesting for evaluation of post-prostatectomy status.

Another uniquely identified protein, connected with PSM status was galectin-3-binding protein (also named Mac-2BP or tumor-associated antigen $90 \mathrm{~K}$ ) that is a highly glycosylated secreted protein, capable of inducing the expression of number of cytokines (IL-1, IF-2 and IL-6) (40). Previous studies have indicated that galectin-3-binding protein promotes tumor metastasis and that the tumor promotion mechanism in metastasis is associated with galectins (41). Furthermore, it was revealed that galectin-3-binding proteins enhance tumor cell adhesion, which may aid tumor cells to avoid apoptosis and is thus highly expressed in PCa samples (42). Although the potential of serum galectin-3-binding protein was discussed in several reports $(40,42,43)$, to our knowledge, this is the first report, showing its possible diagnostic utilization in analysis of urinary specimens.

L-lactate dehydrogenase $\mathrm{C}$ chain or the cancer/testis antigen 32 is typically expressed in normal male germ cells but are silent in normal somatic cells. Nevertheless, they are aberrantly expressed in several types of cancer, including PCa (44). Several studies shown that the expression of L-lactate dehydrogenase $\mathrm{C}$ chain is frequently associated with higher grade lesions and advanced disease with a poorer outcome $(45,46)$, which is consistent with the general fact that PSM is more often linked with higher Gleason score and higher pathologic stage (47) (higher TNM and GS of PSM subjects are shown in Table I).

In conclusion, our examination of urinary proteomes of human PCa specimens identified differences between groups of patients with positive and negative surgical margins after radical prostatectomy. The significance of these findings in the context of presence of PSM is represented by molecular changes leading to alterations in biochemical pathways, hopefully related to the presence of residual tumor after surgical treatment failure. Further evaluation of proteomes of PSM/NSM patients and observation of their biochemical and clinical recurrence will be needed to address a potential significance of urinary proteins in this phenomenon. Ultimately, develop- ment of combination of genomic-proteomic approaches for monitoring of biological processes will be fundamental in further endeavors to understand the PCa and PCa-related statuses in detail.

\section{Acknowledgements}

The authors are grateful to CEITEC CZ.1.05/1.1.00/02.0068 and research grant IGA MZ CR NT13472-4 for financial support.

\section{References}

1. Arnold M, Karim-Kos HE, Coebergh JW, Byrnes G, Antilla A, Ferlay J, Renehan AG, Forman D and Soerjomataram I: Recent trends in incidence of five common cancers in 26 European countries since 1988: Analysis of the European Cancer Observatory. Eur J Cancer 51: 1164-1187, 2015.

2. Luengo-Fernandez R, Leal J, Gray A and Sullivan R: Economic burden of cancer across the European Union: A population-based cost analysis. Lancet Oncol 14: 1165-1174, 2013.

3. Sakr WA, Haas GP, Cassin BF, Pontes JE and Crissman JD: The frequency of carcinoma and intraepithelial neoplasia of the prostate in young male patients. J Urol 150: 379-385, 1993.

4. Siegel R, Naishadham D and Jemal A: Cancer statistics, 2012. CA Cancer J Clin 62: 10-29, 2012.

5. Haas GP, Delongchamps N, Brawley OW, Wang CY and de la Roza G: The worldwide epidemiology of prostate cancer: Perspectives from autopsy studies. Can J Urol 15: 3866-3871, 2008.

6. Walsh PC, Partin AW and Epstein JI: Cancer control and quality of life following anatomical radical retropubic prostatectomy: Results at 10 years. J Urol 152: 1831-1836, 1994.

7. Watson RB, Civantos F and Soloway MS: Positive surgical margins with radical prostatectomy: Detailed pathological analysis and prognosis. Urology 48: 80-90, 1996.

8. Cheng L, Darson MF, Bergstralh EJ, Slezak J, Myers RP and Bostwick DG: Correlation of margin status and extraprostatic extension with progression of prostate carcinoma. Cancer 86: 1775-1782, 1999.

9. Vesely S, Jarolim L, Duskova K, Schmidt M, Dusek P and Babjuk M: The use of early postoperative prostate-specific antigen to stratify risk in patients with positive surgical margins after radical prostatectomy. BMC Urol 14: 79, 2014.

10. Aebersold R, Anderson L, Caprioli R, Druker B, Hartwell L and Smith R: Perspective: A program to improve protein biomarker discovery for cancer. J Proteome Res 4: 1104-1109, 2005.

11. Bergman $\mathrm{N}$ and Bergquist J: Recent developments in proteomic methods and disease biomarkers. Analyst (Lond) 139: 3836-3851, 2014.

12. Heger Z, Kominkova M, Cernei N, Krejcova L, Kopel P, Zitka O, Adam V and Kizek R: Fluorescence resonance energy transfer between green fluorescent protein and doxorubicin enabled by DNA nanotechnology. Electrophoresis 35: 3290-3301, 2014.

13. Vyslouzilova L, Krizkova S, Anyz J, Hynek D, Hrabeta J, Kruseova J, Eckschlager T, Adam V, Stepankova O and Kizek R: Use of brightness wavelet transformation for automated analysis of serum metallothioneins- and zinc-containing proteins by western blots to subclassify childhood solid tumours. Electrophoresis 34: 1637-1648, 2013.

14. Shevchenko A, Tomas H, Havlis J, Olsen JV and Mann M: In-gel digestion for mass spectrometric characterization of proteins and proteomes. Nat Protoc 1: 2856-2860, 2006.

15. Oh J, Pyo JH, Jo EH, Hwang SI, Kang SC, Jung JH, Park EK, Kim SY, Choi JY and Lim J: Establishment of a near-standard two-dimensional human urine proteomic map. Proteomics 4: 3485-3497, 2004.

16. Rehman I, Azzouzi AR, Catto JWF, Allen S, Cross SS, Feeley K, Meuth M and Hamdy FC: Proteomic analysis of voided urine after prostatic massage from patients with prostate cancer: A pilot study. Urology 64: 1238-1243, 2004.

17. Ye B, Skates S, Mok SC, Horick NK, Rosenberg HF, Vitonis A, Edwards D, Sluss P, Han WK, Berkowitz RS, et al: Proteomic-based discovery and characterization of glycosylated eosinophil-derived neurotoxin and $\mathrm{COOH}$-terminal osteopontin fragments for ovarian cancer in urine. Clin Cancer Res 12: 432-441, 2006. 
18. Botezatu I, Serdyuk O, Potapova G, Shelepov V, Alechina R, Molyaka Y, Ananév V, Bazin I, Garin A, Narimanov M, et al: Genetic analysis of DNA excreted in urine: A new approach for detecting specific genomic DNA sequences from cells dying in an organism. Clin Chem 46: 1078-1084, 2000.

19. Oh J, Wilson L, Kirk M, Deshane J and Kim H: Proteomics of normal human and prostate cancer urines. FASEB J 17: 759.757, 2003.

20. Kshirsagar B and Wiggins RC: A map of urine proteins based on one-dimensional SDS-polyacrylamide gel electrophoresis and western blotting using one microliter of unconcentrated urine. Clin Chim Acta 158: 13-22, 1986.

21. Zaragoza C, Barrera R, Centeno F, Tapia JA and Mañe MC: Canine pyometra: A study of the urinary proteins by SDS-PAGE and western blot. Theriogenology 61: 1259-1272, 2004.

22. Le Bricon T, Erlich D, Bengoufa D, Dussaucy M, Garnier JP and Bousquet B: Sodium dodecyl sulfate-agarose gel electrophoresis of urinary proteins: Application to multiple myeloma. Clin Chem 44: 1191-1197, 1998

23. Marshall T and Williams KM: High resolution two-dimensional electrophoresis of human urinary proteins. Anal Chim Acta 372: 147-160, 1998

24. Thongboonkerd V, McLeish KR, Arthur JM and Klein JB: Proteomic analysis of normal human urinary proteins isolated by acetone precipitation or ultracentrifugation. Kidney Int 62 : 1461-1469, 2002.

25. Adachi J, Kumar C, Zhang Y, Olsen JV and Mann M: The human urinary proteome contains more than 1500 proteins, including a large proportion of membrane proteins. Genome Biol 7: R80, 2006.

26. Day ML, Zhao X, Vallorosi CJ, Putzi M, Powell CT, Lin C and Day KC: E-cadherin mediates aggregation-dependent survival of prostate and mammary epithelial cells through the retinoblastoma cell cycle control pathway. J Biol Chem 274: 9656-9664, 1999.

27. Cheng L, Nagabhushan M, Pretlow TP, Amini SB and Pretlow TG: Expression of E-cadherin in primary and metastatic prostate cancer. Am J Pathol 148: 1375-1380, 1996.

28. Umbas R, Isaacs WB, Bringuier PP, Schaafsma HE, Karthaus HF, Oosterhof GO, Debruyne FM and Schalken JA: Decreased E-cadherin expression is associated with poor prognosis in patients with prostate cancer. Cancer Res 54: 3929-3933, 1994.

29. Giroldi LA and Schalken JA: Decreased expression of the intercellular adhesion molecule E-cadherin in prostate cancer: Biological significance and clinical implications. Cancer Metastasis Rev 12: 29-37, 1993.

30. Shimamura T, Sakamoto M, Ino Y, Sato Y, Shimada K, Kosuge T, Sekihara $\mathrm{H}$ and Hirohashi S: Dysadherin overexpression in pancreatic ductal adenocarcinoma reflects tumor aggressiveness: Relationship to e-cadherin expression. J Clin Oncol 21: 659-667, 2003.

31. Duffy MJ: Tumor markers in clinical practice: A review focusing on common solid cancers. Med Princ Pract 22: 4-11, 2013.

32. Gutman EB, Sproul EE and Gutman AB: Significance of increased phosphatase activity of bone at the site of osteoplastic metastases secondary to carcinoma of the prostate gland. Am J Cancer 28: 485-495, 1936.
33. Wang MC, Papsidero LD, Kuriyama M, Valenzuela LA, Murphy GP and Chu TM: Prostate antigen: A new potential marker for prostatic cancer. Prostate 2: 89-96, 1981.

34. Morikawa W, Yamamoto K, Ishikawa S, Takemoto S, Ono M, Fukushi J, Naito S, Nozaki C, Iwanaga S and Kuwano M: Angiostatin generation by cathepsin D secreted by human prostate carcinoma cells. J Biol Chem 275: 38912-38920, 2000.

35. Lim JTE, Mansukhani M and Weinstein IB: Cyclin-dependent kinase 6 associates with the androgen receptor and enhances its transcriptional activity in prostate cancer cells. Proc Natl Acad Sci USA 102: 5156-5161, 2005.

36. Choi YJ and Anders L: Signaling through cyclin D-dependent kinases. Oncogene 33: 1890-1903, 2014.

37. Hanahan D and Weinberg RA: Hallmarks of cancer: The next generation. Cell 144: 646-674, 2011.

38. Finn RS, Dering J, Conklin D, Kalous O, Cohen DJ, Desai AJ, Ginther C, Atefi M, Chen I, Fowst C, et al: PD 0332991, a selective cyclin D kinase $4 / 6$ inhibitor, preferentially inhibits proliferation of luminal estrogen receptor-positive human breast cancer cell lines in vitro. Breast Cancer Res 11: R77, 2009.

39. Tan MHE, Li J, Xu HE, Melcher K and Yong EL: Androgen receptor: Structure, role in prostate cancer and drug discovery. Acta Pharmacol Sin 36: 3-23, 2015.

40. Sardana G, Marshall J and Diamandis EP: Discovery of candidate tumor markers for prostate cancer via proteomic analysis of cell culture-conditioned medium. Clin Chem 53: 429-437, 2007.

41. Inohara $\mathrm{H}$, Akahani $\mathrm{S}$, Koths $\mathrm{K}$ and Raz $\mathrm{A}$ : Interactions between galectin-3 and Mac-2-binding protein mediate cell-cell adhesion. Cancer Res 56: 4530-4534, 1996.

42. Hu J, He J, Kuang Y, Wang Z, Sun Z, Zhu H and Liu X: Expression and significance of $90 \mathrm{~K} / \mathrm{Mac}-2 \mathrm{BP}$ in prostate cancer. Exp Ther Med 5: 181-184, 2013.

43. Srirajaskanthan R, Caplin ME, Waugh MG, Watkins J, Meyer T, Hsuan JJ and Beaumont NJ: Identification of Mac-2-binding protein as a putative marker of neuroendocrine tumors from the analysis of cell line secretomes. Mol Cell Proteomics 9: 656-666, 2010.

44. Scanlan MJ, Simpson AJG and Old LJ: The cancer/testis genes: Review, standardization, and commentary. Cancer Immun 4: $1-15,2004$.

45. Gure AO, Chua R, Williamson B, Gonen M, Ferrera CA, Gnjatic S, Ritter G, Simpson AJ, Chen YT, Old LJ, et al: Cancertestis genes are coordinately expressed and are markers of poor outcome in non-small cell lung cancer. Clin Cancer Res 11: 8055-8062, 2005.

46. Andrade VCC, Vettore AL, Almeida MSS, et al: Prognostic impact of cancer testis antigens expression in advanced stage multiple myeloma patients. Blood 110: 257B-257B, 2007.

47. Marcovich R, Wojno KJ, Wei JT, Rubin MA, Montie JE and Sanda MG: Bladder neck-sparing modification of radical prostatectomy adversely affects surgical margins in pathologic T3a prostate cancer. Urology 55: 904-908, 2000. 